\title{
Contamination Evaluation and Source Identification of Heavy Metals in the Sediments from the Lishui River Watershed, Southern China
}

\author{
Fang Shen ${ }^{1}$, Longjiang Mao ${ }^{1,2, *}$, Runxia Sun ${ }^{1}$, Jijing Du ${ }^{1}$, Zhihai Tan ${ }^{3}$ and Min Ding ${ }^{4}$ \\ 1 School of Marine Sciences, Nanjing University of Information Science and Technology, Nanjing 210044, \\ China; mlj1214@nuist.edu.cn (F.S.); Sunrunxia@nuist.edu.cn (R.S.); djijing@163.com (J.D.) \\ 2 Jiangsu Research Center for Ocean Survey Technology, Nanjing University of Information Science and \\ Technology, Nanjing 210044, China \\ 3 Environmental and Chemical Engineering College, Xi'an Poly-technic University, Xi'an 710048, China; \\ tonishtan@163.com \\ 4 School of Tourism, Taishan University, Tai'an 271021, China; jndm2612@sohu.com \\ * Correspondence: mlj1214@163.com
}

Received: 8 December 2018; Accepted: 21 January 2019; Published: 25 January 2019

\begin{abstract}
Seven heavy metals ( $\mathrm{Cr}, \mathrm{Mn}, \mathrm{Co}, \mathrm{Ni}, \mathrm{Cu}, \mathrm{Zn}, \mathrm{Pb})$ were measured in surface sediments from the Lishui River watershed, an area with increased soil erosion in China. The mean concentrations of heavy metals were $61.20 \mathrm{mg} / \mathrm{kg}(\mathrm{Cr}), 757.15 \mathrm{mg} / \mathrm{kg}(\mathrm{Mn}), 9.39 \mathrm{mg} / \mathrm{kg}$ (Co), $25.31 \mathrm{mg} / \mathrm{kg}(\mathrm{Ni})$, $22.84 \mathrm{mg} / \mathrm{kg}(\mathrm{Cu}), 91.66 \mathrm{mg} / \mathrm{kg}(\mathrm{Zn})$, and $40.19 \mathrm{mg} / \mathrm{kg}(\mathrm{Pb})$, respectively. The spatial distribution of heavy metals was site-specific, exhibiting a remarkably high level in the sampling stations with intense agricultural activities (Lixian) and industrial activities (Jinshi). Contamination indexes including contamination factor, pollution load index, nemerow multi-factor index, potential ecological risk index, and human health risk were used to assess the pollution degree of the river sediments. The results indicated the pollution degree of heavy metals decreased in the order of $\mathrm{Mn}>\mathrm{Pb}>\mathrm{Zn}>\mathrm{Cr}>\mathrm{Cu}>\mathrm{Ni}$ $>$ Co. Heavy metals resulted in non-pollution to moderate pollution, with low ecological risk and an acceptable carcinogenic risk caused by $\mathrm{Cr}$ and $\mathrm{Ni}$ for children and adults. Person's correlation analysis and principal component analysis, coupled with cluster analysis, revealed that the sediments from the Lishui River were mainly influenced by two sources. $\mathrm{Cr}, \mathrm{Co}, \mathrm{Ni}$, and $\mathrm{Cu}$ were mainly derived from natural sources, while $\mathrm{Mn}, \mathrm{Zn}$, and $\mathrm{Pb}$ originated from agricultural and industrial activities, mining, and vehicular traffic.
\end{abstract}

Keywords: heavy metals; surface sediments; contamination evaluation; source identification; the Lishui River

\section{Introduction}

According to statistics, more than $99 \%$ of heavy metals entering aquatic system can be stored in the sediment indifferent ways [1]. River sediments are important repositories, sinks, and carriers for heavy metals $[2,3]$. They play an important role in assessing metal contamination and tracing contamination sources [4]. Heavy metals can inflict serious environmental damage in the surroundings due to their toxicity, persistence, and bioaccumulation [3]. Following the frequency of natural and anthropogenic activities and the discharge of heavy metals into rivers, contamination is ubiquitous in the aquatic environment [5]. The natural sources of heavy metals mainly include geological weathering, soil erosion, and airborne dust [6]. Anthropogenic activities are the major cause of heavy metal pollution in the aquatic environment, such as industrial discharges, vehicular exhaust, mining operations, agricultural cultivation, and atmospheric precipitation [6,7]. Heavy metals drill through multiple 
biogeochemical cycles and eventually enter the human food chain, which brings about bioaccumulation and bio-magnification, and poses a potential threat to human health [8-10]. Heavy metal pollution, a widespread global problem, has attracted great concern due to the increasing concern of human health [9]. Therefore, it is essential to study the concentration, distribution, influence, and sources of heavy metals in the sediment to protect human health and environment.

The Lishui River is one of the four major rivers (Lishui River, Xiangiiang River, Zishui River, and Yuanjiang River) in Hunan Province, Southern China. The Lishui River basin is a densely populated area with a population of nearly 3.91 million and a significant agricultural production base in the national, especially in the Liyang plain [11,12]. The Liyang plain, situated on the northwestern bank of Dongting Lake, has crisscrossing rivers mainly composed of the Lishui River and its branches (the Danshui River and Censhui River) [13]. The Lishui River is vital for agricultural and domestic water supply in this area [12]. However, the environmental pressure of pollutants increasing with the economy of the Lishui River basin has achieved a steady and rapid growth in recent years [14,15]. The Lishui River flows through several agricultural and industrial areas and finally enters Dongting Lake. Severe heavy metal pollution has been found in the sediment from Dongting Lake [16]. The Lishui River is both the most sand-filled and the most serious soil erosion river among the Dongting Lake water system [17]. Hence, it is indispensable to study the heavy metal pollution in the sediments from the Lishui River.

The principal aims of this research are to (1) measure the contamination and investigate the distribution of seven heavy metals $(\mathrm{Cr}, \mathrm{Mn}, \mathrm{Co}, \mathrm{Ni}, \mathrm{Cu}, \mathrm{Zn}$, and $\mathrm{Pb})$, (2) use sediment quality indicators including the contamination factor, the pollution load index, and the nemerow multi-factor index to assess the pollution degree of river sediments, (3) use potential ecological risk and health index to assess the risk of heavy metals, and (4) use multivariate analysis to distinguish the possible sources of heavy metals.

\section{Materials and Methods}

\subsection{Background of Study Area}

The Lishui River $\left(29^{\circ} 30^{\prime}-30^{\circ} 12^{\prime} \mathrm{N}, 109^{\circ} 30^{\prime}-112^{\circ} 00^{\prime} \mathrm{E}\right)$, located in the northwest of Hunan Province, is the fourth largest river in the Dongting Lake basin [14]. The Lishui River originates from the Chinese fir community in Sangzhi County and flows through six counties (Sangzhi County, Dayong County, Cili County, Shimen County, Lixian County, and Jinshi County) from northwest and to southeast, and finally enters Dongting Lake $[18,19]$. The trunk steam and eight tributaries are collectively referred to as Jiuli. The Lishui River, with the spatial extent of $18,496 \mathrm{~km}^{2}$ and the main stream of $388 \mathrm{~km}$, has an abundant and concentrated watercourse [20]. Its mean annual runoff is $1.70 \times 10^{10} \mathrm{~m}^{3}$, and the natural drop is up to $1439 \mathrm{~m}$, leading abundant hydropower resources [11]. The upper reach of the Lishui River flows through mountains and valleys, exposing storm runoff and bedrock; the middle reach flows through hills and basins; the downstream is plain and opening flat terrain, where population and economic activities are concentrated [12,19]. In the consideration of geology, population, and production, this research chose the downstream of the Lishui River as the study area. The study area covered Shimen County, Lixian County, and Jinshi County, situated in the south of the Liyang plain (Figure 1). This region features a subtropical climate, characterized by warm and humid summers, and cool and dry winters $[11,13]$. With an annual mean temperature of $16-17^{\circ} \mathrm{C}$, the annual mean precipitation is less than $1300 \mathrm{~mm}[11,13]$.

\subsection{Sampling and Sample Preparation}

Surface sediments were sampled from 21 locations across the Lishui River in the summer of 2016, as illustrated in Figure 1. Using a pre-cleaned and acid washed PVC spade, all sediment samples $(0-5 \mathrm{~cm})$ were immediately placed in acid-washed polyethylene bags. For the geochemical analysis of the sediments, all samples were transported to the laboratory and air-dried for two weeks to ambient temperature. 


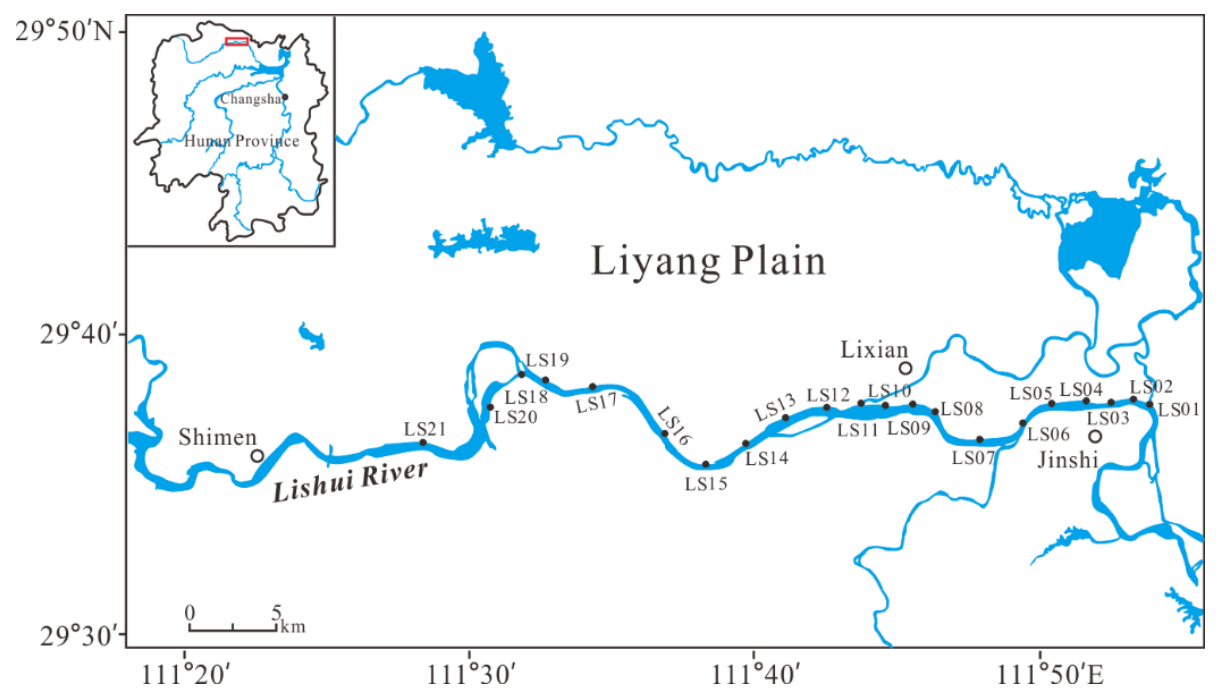

Figure 1. Sediment sampling stations in the Lishui River, China.

\subsection{Analytical Methods}

All of the samples for the geochemical analysis were powdered in an agate mortar [21]. The acid digestion method was applied for the extraction of heavy metals using $\mathrm{HCl}-\mathrm{HNO}_{3}-\mathrm{HF}-\mathrm{HClO}_{4}$. Fractions of approximately $100 \mathrm{mg}$ of powdered sediments were digested to a mixture of $10 \mathrm{~mL}$ of $\mathrm{HCl}(\rho=1.19 \mathrm{~g} / \mathrm{mL}), 10 \mathrm{~mL}$ of $\mathrm{HNO}_{3}(\rho=1.42 \mathrm{~g} / \mathrm{mL}), 10 \mathrm{~mL}$ of $\mathrm{HF}(\rho=1.49 \mathrm{~g} / \mathrm{mL})$, and $10 \mathrm{~mL}$ of $\mathrm{HClO}_{4}(\rho=1.68 \mathrm{~g} / \mathrm{mL})$ digested at $180^{\circ} \mathrm{C}$ in a microwave oven (ETHOS TOUCH CONTROL, Milestone Inc., Via Fatebenefratelli, 1/5 24010 Sorisole (BG), Italy) [22]. The obtained suspension liquid was then filtered using a membrane filter [8]. The concentrations of $\mathrm{Cr}, \mathrm{Mn}, \mathrm{Co}, \mathrm{Ni}, \mathrm{Cu}, \mathrm{Zn}$, and $\mathrm{Pb}$ in the sediment from the Lishui River were quantified with high-resolution inductively coupled plasma mass spectroscopy (HR-ICP-MS, Element II) at the State Key Laboratory for Deposits Research of Nanjing University. In order to guarantee the accuracy of the results, adequate quality assurance/quality control (QA/QC) was adopted in all aspects of the study [23]. The accuracy of the analysis was controlled by using reagent blanks, duplicate samples, and certified geochemical reference materials with a deviation of $<5 \%$.

\subsection{Heavy Metal Concentration and Contamination Assessment}

\subsubsection{Contamination Factor}

The contamination factor $(C F)$, a single index, is considered to be a simple and effective tool in monitoring the heavy metal contamination [24]. CF is calculated using the following equation:

$$
C F_{i}=C_{i} / B_{i}
$$

where $C_{i}$ and $B_{i}$ are the measured concentration and the background value of metal $i$, respectively. $C F_{i}$ is a contamination factor of heavy metal in the sediments. The contamination factor distinguishes four classes of quality for sediments as given in Table 1 [24]. The background concentrations of $\mathrm{Cr}, \mathrm{Mn}, \mathrm{Co}$, $\mathrm{Ni}, \mathrm{Cu}, \mathrm{Zn}$, and $\mathrm{Pb}$ are 71.3, 459.0, 14.6, 31.9, 27.3, 94.4, and $29.7 \mathrm{mg} / \mathrm{kg}$ [25].

Table 1. The classes of contamination factor $(C F)$ and potential ecological risk $[24,26]$.

\begin{tabular}{ccccc}
\hline CF & Contamination Degree & $E_{r}^{i}$ & RI & Potential Ecological Risk \\
\hline $\mathrm{CF}_{\mathrm{i}}<1$ & Low & $E_{r}^{i}<40$ & $\mathrm{RI}<150$ & Low \\
$1 \leq \mathrm{CF}_{\mathrm{i}}<3$ & Moderate & $40 \leq E_{r}^{i}<80$ & $150 \leq \mathrm{RI}<300$ & Moderate \\
$3 \leq \mathrm{CF}_{\mathrm{i}}<6$ & Considerable & $80 \leq E_{r}^{i}<160$ & $300 \leq \mathrm{RI}<600$ & Considerable \\
$\mathrm{CF}_{\mathrm{i}} \geq 6$ & Very high & $160 \leq E_{r}^{i}<320$ & & High \\
& & $E_{r}^{i} \geq 320$ & $\mathrm{RI} \geq 600$ & Very high \\
\hline
\end{tabular}




\subsubsection{Pollution Load Index}

The pollution load index (PLI) has been used to assess the comprehensive level of heavy metals for site, zone, or estuary [26]. The PLI value for a site in the sediment is calculated with the formula

$$
P L I=\sqrt[n]{\prod_{i=1}^{n} C F_{i}}, C F_{i}=C_{i} / B_{i}
$$

where $C F_{i}$ is the ratio between the measured concentration $\left(C_{i}\right)$ and the background value $\left(B_{i}\right)$ of the heavy metal $i ; n$ is the number of heavy metals. $P L I>1$ means polluted and $P L I<1$ implies unpolluted [26].

\subsubsection{Nemerow Multi-Factor Index}

The nemerow multi-factor index $(P I)$, taking into consideration the most polluting factors in particular, can be used to assess the status of comprehensive pollution caused by all the heavy metals in the sediments, because different heavy metals may have impacts in the same station [27]. The nemerow multi-factor index $(P I)$ is defined as

$$
P I=\sqrt[2]{\frac{\left(C F_{\text {imax }}\right)^{2}+\left(C F_{\text {iave }}\right)^{2}}{2}}, C F_{i}=C_{i} / B_{i}
$$

where $C F_{i}$ is the ratio between the measured concentration $\left(C_{i}\right)$ and background value $\left(B_{i}\right)$ of the heavy metal $i ; C F_{\text {imax }}$ and $C F_{\text {iave }}$ represent the maximum contamination and average of contamination factors, respectively. $P I$ is the nemerow multi-factor index, whose values are categorized as follows: $P I<1$ : unpolluted; $1 \leq P I<2.5$ : lowly polluted; $2.5 \leq P I<7$ : moderately polluted; $P I \geq 7$ : highly polluted [28].

\subsubsection{Potential Ecological Risk Index}

The potential ecological risk index $(R I)$ is used to assess the potential ecological risk of a given contaminant in sediments according to the toxicity of heavy metals and response of the environment [24]. The formulas of potential ecological risk index described by Hankanson are expressed as

$$
C_{r}^{i}=C_{f}^{i} / C_{n}^{i}, E_{r}^{i}=T_{r}^{i} \times C_{r}^{i}, R I=\sum E_{r}^{i}
$$

where $C_{r}^{i}$ is the pollution factor of the heavy metal $i ; C_{f}^{i}$ and $C_{n}^{i}$ are the measured concentration and background value, respectively; $T_{r}^{i}$ is the toxic-response factor for a given substance (i.e., $\mathrm{Cr}=2$, $\mathrm{Mn}=\mathrm{Zn}=1, \mathrm{Co}=\mathrm{Ni}=\mathrm{Cu}=\mathrm{Pb}=5) ; E_{r}^{i}$ is the potential ecological risk index of the metal $i$; $R I$ represents the potential ecological risk index of all heavy metals for a region, which is the sum of individual potential factor. The $E_{r}^{i}$ and $R I$ are divided into five and four classes depending on the apart values given in Table 1, respectively [24].

\subsection{Potential Human Health Risk}

Human risk assessment is generally used to estimate the risk caused by the heavy metals of a known amount for human beings after chemical exposure [29]. Health risk assessment can be determined by the non-carcinogenic and carcinogenic risk for both adults and children. Hazard identification, exposure assessment, dose-response assessment, and risk characterization are the key elements of health risk assessment [30]. To predict the human health risk caused by the exposure of heavy metals, chronic daily intake $(C D I)(\mathrm{mg} / \mathrm{kg} /$ day $)$ through incidental ingestion $\left(C D I_{\text {ingest }}\right)$ and dermal contact $\left(C D I_{\text {dermal }}\right)$ was determined by the following formulas [31]:

$$
\begin{aligned}
& C D I_{\text {ingest }}=\frac{C S \times I R \times C F \times F I \times E F \times E D}{B W \times A T} \\
& C D I_{\text {dermal }}=\frac{C S \times C F \times S A \times A F \times A B S \times E F \times E D}{B W \times A T}
\end{aligned}
$$


where CS is the heavy metal concentration in the sediment $(\mathrm{mg} / \mathrm{kg}) ; I R$ is the ingestion rate $(\mathrm{mg} /$ day); $C F$ is the conversion factor $(\mathrm{kg} / \mathrm{mg}) ; F I$ is the fraction ingested from the contaminated source (unitless); the $E F$ of the $C D I_{\text {ingesti }}$ is the exposure frequency (days/year); $E D$ is the exposure duration (years); $B W$ is the average body weight $(\mathrm{kg}) ; A T$ is the average time (days); $S A$ is the exposed surface area of skin $\left(\mathrm{cm}^{2} /\right.$ event); $A F$ is the skin adherence factor $\left(\mathrm{mg} / \mathrm{cm}^{2}\right) ; A B S$ is the dermal absorption factor (unitless); $E F$ of $C D I_{\text {dermal }}$ is the exposure frequency (events/year). The values of the input parameters used to calculate CDI are given in Table 2.

Table 2. The values of parameters used to estimate chronic daily intake (CDI).

\begin{tabular}{cc}
\hline Parameter & Value \\
\hline$I R$ & Child: $200 \mathrm{mg} /$ day; adult: $100 \mathrm{mg} /$ day \\
$C F$ & $1 \times 10^{-6} \mathrm{~kg} / \mathrm{mg}$ \\
$F I$ & 1.0 \\
$E F$ & 350 days $/$ year \\
$E D$ & Child: 6 years; adult: 30 years \\
$B W$ & Child: $15 \mathrm{~kg} ;$ adult: $70 \mathrm{~kg}$ \\
$A T$ & Non-carcinogenic: ED $\times 365$ days $/$ years; carcinogenic: 70 years $\times 365$ days $/$ years \\
$S A$ & Child: $2800 \mathrm{~cm}^{2} ;$ adult: $5700 \mathrm{~cm}^{2}$ \\
$A F$ & Child: $0.2 ;$ adult: 0.07 \\
$A B S$ & 0.001 \\
$E F$ & 1 events $/$ day $\times 350$ days $/$ year \\
\hline
\end{tabular}

Adapted from US Environmental Protection Agency [31,32].

\subsubsection{Non-Carcinogenic Risk}

Hazard index $(H I)$ is characterized by the sum of hazard quotients $(H Q)$, indicating the cumulative non-carcinogenic. $H Q$ represents the ratio of the chronic daily intake $(C D I)$ and the corresponding reference dose (RfD). The RfD values of $\mathrm{Cr}, \mathrm{Mn}, \mathrm{Co}, \mathrm{Ni}, \mathrm{Cu}, \mathrm{Zn}$, and $\mathrm{Pb}$ are $0.003,0.14,0.02,0.02,0.0371$, 0.3 , and $0.0035 \mathrm{mg} / \mathrm{kg} /$ day [33]. A value of $H I$ below 1 means no significant non-carcinogenic risk; a value of $H I$ surpassing 1 indicates adverse non-carcinogenic risk effects may occur [32]. $H Q$ and $H I$ are expressed as follows [31]:

$$
\begin{aligned}
& H Q=C D I / R f D \\
& H I=\sum H Q=H Q_{\text {ingest }}+H Q_{\text {dermal }}
\end{aligned}
$$

\subsubsection{Carcinogenic Risk}

Carcinogenic risk $(C R)$ is estimated with the product of the chronic daily intake $(C D I)$ and the cancer slope factor (CSF) over a lifetime. The cancer slope factor (CSF) plays a key role in convention that the daily toxin intake changes into the incremental risk of an individual developing cancer. Due to the lake of $C S F$ values, only the carcinogenic risk of $\mathrm{Cr}, \mathrm{Ni}$, and $\mathrm{Pb}$ was estimated. The CSF values of $\mathrm{Cr}, \mathrm{Ni}$, and $\mathrm{Pb}$ are $0.5,0.84$, and 0.0085 , respectively [33]. $\mathrm{CR}$ through an individual exposure pathway can be summed to generate the total cancer risk (TCR). A value of TCR ranging from $1 \times 10^{-6}$ to $1 \times 10^{-4}$ is considered an acceptable or tolerant scope [33]. A TCR less than $1 \times 10^{-6}$ doesnot have dramatic effects on human health, while a TCR exceeding $1 \times 10^{-4}$ is regarded as unacceptable [33]. $C R$ and TCR are calculated by the following equations [31]:

$$
\begin{aligned}
& C R=C D I \times C S F \\
& T C R=\sum C R=C R_{\text {ingest }}+C R_{\text {dermal }}
\end{aligned}
$$

\subsection{Multivariate Analysis}

Multivariate analysis, including Pearson's correlation analysis, principal component analysis (PCA), and cluster analysis (CA), is an effective tool to identify the sources of heavy metals $[34,35]$. Pearson's correlation analysis is used to evaluate the relativity between heavy metals elements. Principal 
component analysis (PCA) is used to reduce the dimension of data and extract highly correlated heavy metal elements into independent factors. Cluster analysis (CA) classifies heavy metal elements into different classes, and the classes required for clustering are unknown. Multivariate analysis was carried out using the SPSS statistical package.

\section{Results and Discussion}

\subsection{Heavy Metal Concentration and Spatial Distribution}

Figure 2 presented the concentrations of heavy metals $(\mathrm{Cr}, \mathrm{Mn}, \mathrm{Co}, \mathrm{Ni}, \mathrm{Cu}, \mathrm{Zn}$, and $\mathrm{Pb})$ in the sediment collected from the Lishui River. The concentrations of $\mathrm{Cr}, \mathrm{Mn}, \mathrm{Co}, \mathrm{Ni}, \mathrm{Cu}, \mathrm{Zn}$, and $\mathrm{Pb}$ ranged from 35.01 to 120.94 , from 366.66 to 1604.32 , from 5.04 to 13.05 , from 13.14 to 45.54 , from 11.40 to 34.13 , from 39.56 to 207.16 , and from 17.25 to $159.91 \mathrm{mg} / \mathrm{kg}$, respectively. The mean concentrations of the studied heavy metals descended in the order of $\mathrm{Mn}(757.15 \mathrm{mg} / \mathrm{kg})>\mathrm{Zn}(91.66 \mathrm{mg} / \mathrm{kg})>\mathrm{Cr}$ $(61.20 \mathrm{mg} / \mathrm{kg})>\mathrm{Pb}(40.19 \mathrm{mg} / \mathrm{kg})>\mathrm{Ni}(25.31 \mathrm{mg} / \mathrm{kg})>\mathrm{Cu}(22.84 \mathrm{mg} / \mathrm{kg})>\mathrm{Co}(9.39 \mathrm{mg} / \mathrm{kg})$. The concentrations of the Lishui River were compared with the concentrations reported from other rivers in China and other countries (Table 3). The trend was the same as that in the Zishui River flowing into the Dongting Lake, but different from that in the Xiangjiang River [36]. The levels of heavy metal in the present study were lower than those in the Zishui River and the Xiangjiang River [36,37]. However, the concentrations of heavy metals in the Lishui River were higher than those in the rivers in Guangdong, one of the most developed regions in China [5]. The concentrations of heavy metals $(\mathrm{Cr}, \mathrm{Mn}, \mathrm{Co}, \mathrm{Ni}, \mathrm{Cu}$, and $\mathrm{Zn}$ ) in the Lishui River were higher than the values investigated in the Zahuapan River in Mexico, a reference river in eco-toxicological studies [38]. The characteristics of heavy metal concentrations had a big difference between the Lishui River and the rivers in Mexico (Zahuapan River, Atoyac River). The concentration of $\mathrm{Mn}$ in the Lishui River was much larger than that of the Zahuapan River and the Atoyac River, while the concentrations of $\mathrm{Cr}$ and $\mathrm{Pb}$ in the Lishui River were much lower than the concentrations in the Zahuapan River and the Atoyac River [39].

Table 3. Heavy metal concentrations in the sediments from the Lishui River and other selected rivers.

\begin{tabular}{|c|c|c|c|c|c|c|c|c|}
\hline \multirow{2}{*}{ Name of the River, Country } & \multicolumn{7}{|c|}{ Heavy Metal Concentrations (mg/kg) } & \multirow{2}{*}{ References } \\
\hline & $\mathrm{Cr}$ & Mn & Co & $\mathrm{Ni}$ & $\mathrm{Cu}$ & $\mathrm{Zn}$ & $\mathrm{Pb}$ & \\
\hline Lishui River, China & 61.20 & 757.15 & 9.39 & 25.31 & 22.84 & 91.66 & 40.19 & This study \\
\hline Zishui River, China & 67.51 & 1322.89 & 16.76 & 34.66 & 34.19 & 141.90 & 35.68 & [36] \\
\hline Xiangjiang River, China & 120.44 & 1805.17 & 23.19 & 57.14 & 101.36 & 443.32 & 214.91 & [37] \\
\hline Rivers in Guangdong Province, China & 21.81 & 325.78 & 4.58 & 15.99 & 15.71 & 60.16 & 26.93 & [5] \\
\hline Zarrin-Gol River, Iran & 37.67 & 286.28 & 8.79 & 12.39 & - & 32.68 & - & [38] \\
\hline Zahuapan River, Mexico & 121.63 & 293.88 & 8.25 & 19.38 & 12.63 & 91.63 & 9.00 & [39] \\
\hline Atoyac River, Mexico & 181.83 & 158.17 & 5.33 & 22.00 & 14.17 & 62.17 & 12.17 & [39] \\
\hline Background value & 71.30 & 459.00 & 14.60 & 31.90 & 27.30 & 94.40 & 29.70 & [25] \\
\hline
\end{tabular}

The highest concentrations of $\mathrm{Cr}$ and Ni were found at Station LS09 $(120.94 \mathrm{mg} / \mathrm{kg}$ for $\mathrm{Cr}$ and $45.54 \mathrm{mg} / \mathrm{kg}$ for $\mathrm{Ni}$, respectively). The levels of $\mathrm{Cr}$ and $\mathrm{Ni}$ in the other sampling sites exhibited slight fluctuations, which were comparable to lower than the respective background values [25]. Sampling Station LS09 is located in Lixian, an important agricultural production base in China. Intensive agricultural activity may be a plausible reason. Previous studies have demonstrated that the abuse of pesticides and phosphate fertilizer in agriculture caused cadmium deposition in the sediments [40]. Elevated levels of $\mathrm{Mn}, \mathrm{Zn}$, and $\mathrm{Pb}$ were all observed in the sampling stations next to Jinshi, a developed industrial city in China. $\mathrm{Co}$ and $\mathrm{Cu}$ both showed similar concentrations among sampling sites. 

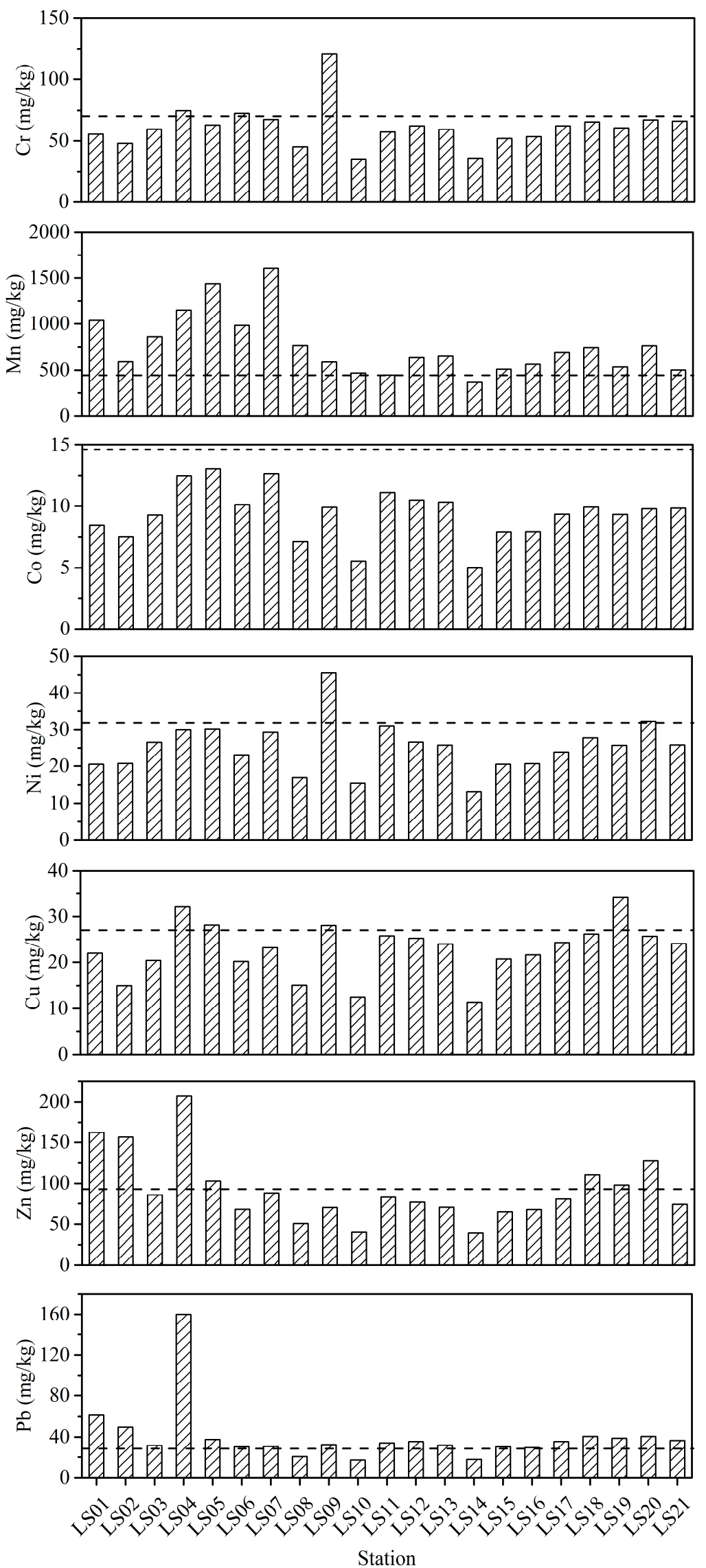

Figure 2. Heavy metals concentrations $(\mathrm{mg} / \mathrm{kg}$ ) in the sediment from the Lishui River. 


\subsection{Heavy Metal Contamination Assessment}

In order to comprehensively understand the contamination of heavy metals in the sediments of the Lishui River, the contamination factor, pollution load index, and nemerow multi-factor index were applied to evaluate the pollution levels in the present study (Figure 3). The average $C F$ values were 0.86 for $\mathrm{Cr}, 1.65$ for $\mathrm{Mn}, 0.64$ for $\mathrm{Co}, 0.79$ for $\mathrm{Ni}, 0.84$ for $\mathrm{Cu}, 0.97$ for $\mathrm{Zn}$, and 1.35 for $\mathrm{Pb}$, respectively. The results indicated that, overall, the surface sediments in the Lishui River were moderately polluted by $\mathrm{Mn}$ and $\mathrm{Pb}$. In contrast, $\mathrm{Cr}, \mathrm{Ni}, \mathrm{Cu}, \mathrm{Zn}$, and $\mathrm{Co}$ exhibited low concentration. However, it is noteworthy that several sampling sites showed considerable contamination of Mn (LS05 and LS07) and $\mathrm{Pb}$ (LS04), and moderate contamination of Cr (LS09), Ni (LS09), Cu (LS09 and LS19), and Zn (LS01, LS02, LS04, LS05, LS18, and LS20). The PLI and PI values reflected the status of comprehensive pollution caused by all the heavy metals. The PLI and PI ranged from 0.48 to 1.62 and from 0.67 to 4.06 , respectively. This implied heavy metal pollution existed in the sediments from the Lishui River, which was consistent with the results obtained from CF values. The values of PLI indicated that the stations with values greater than 1, expressing the sediment polluted by heavy metals, were LS01, LS04, LS05, LS07, LS09, and LS20. And the three worst stations of heavy metal pollution were LS04 (1.62), LS05 (1.19), and LS07 (1.12). The values of PI exhibited that Stations LS04 (4.07) and LS07 (2.64) were both between 2.5 and 7, meaning moderately polluted, while LS10, LS14, and LS15 were less than 1 , indicating no pollution. The other stations were polluted by lowly by heavy metals on the basis of $P I$ values. Hence, the values of PLI and PI both indicated that the sampling sites between the Jinshi section and the Lixian section of the Lishui River (LS04, LS05, and LS07) were the three heavy metal pollution stations. The pollution of Station LS04 mainly caused by the considerable contamination of Pb. Heavy metal contamination in Stations LS05 and LS07 resulted from the considerable contamination of Mn.

The results of potential ecological risk index were displayed in Figure $3 \mathrm{~b}$. The potential ecological factors $E_{r}^{i}$ of seven heavy metals $(\mathrm{Cr}, \mathrm{Mn}, \mathrm{Co}, \mathrm{Ni}, \mathrm{Cu}, \mathrm{Zn}$, and $\mathrm{Pb}$ ) were all less than 40 . Moreover, the $R I$ values for all stations were all less than 95 . All studied heavy metals posed a low potential ecological risk at the sediment from the Lishui River, and all sampling sites exhibited a low potential ecological risk of heavy metals.

Human health risk caused by heavy metals was assessed by the hazard index (HI) for non-carcinogenic risk and the total cancer risk (TCR) value for carcinogenic risk for both children and adults (Figure 4). The $H I$ values of the studied heavy metals ranged from 0.0017 to 0.5858 for children and from 0.0002 to 0.0628 for adults, respectively. $\mathrm{HI}$ values for children and adults were investigated in the descending order of $\mathrm{Cr}>\mathrm{Pb}>\mathrm{Mn}>\mathrm{Ni}>\mathrm{Cu}>\mathrm{Co}>\mathrm{Zn}$. The results suggested that there would not be a non-carcinogenic risk caused by heavy metals for children and adults, although the $H I$ values for children were an order of magnitude higher than that for adults.

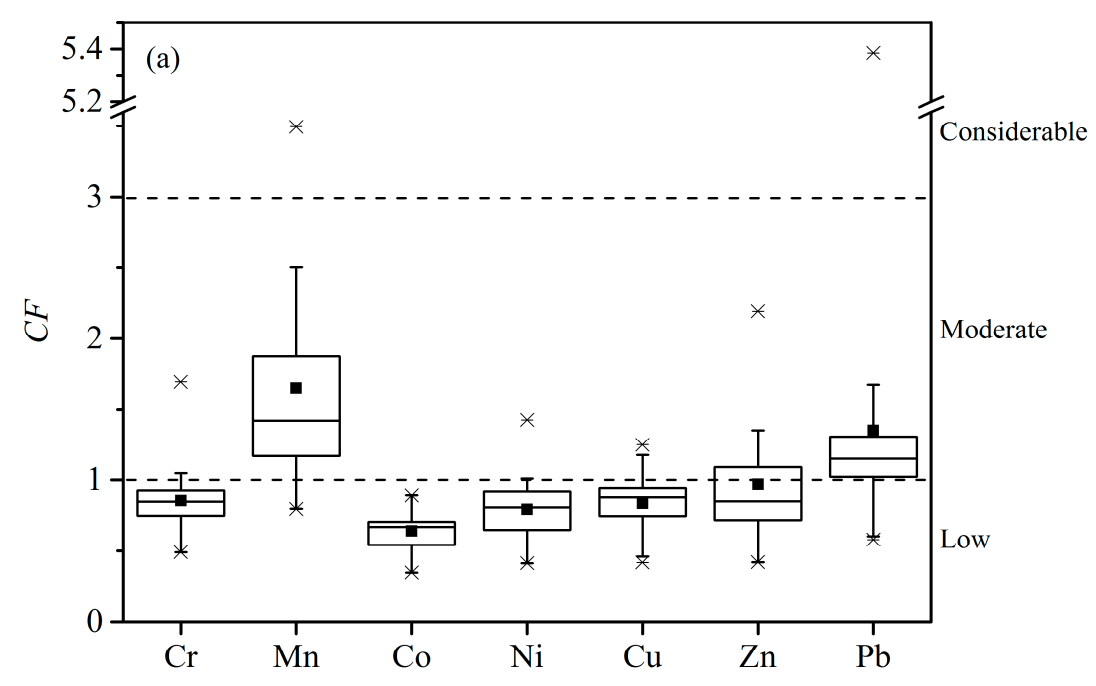

Figure 3. Cont. 


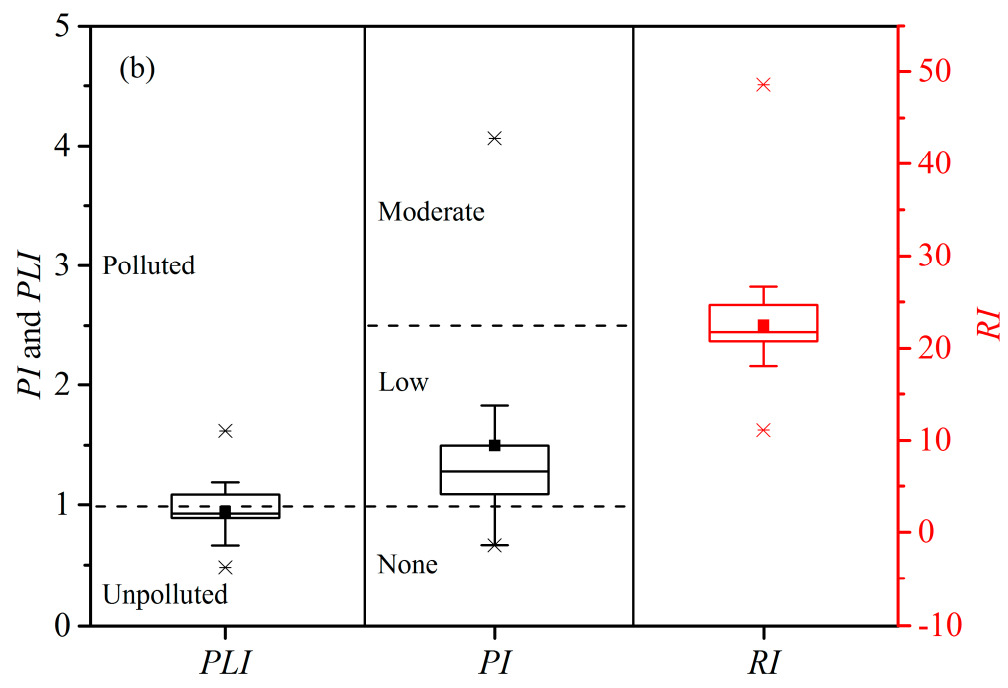

Figure 3. $C F, P L I, P I$, and $R I$ values of heavy metals in the sediment from the Lishui River. (a) $C F$ values; (b) PLI, PI and RI values.
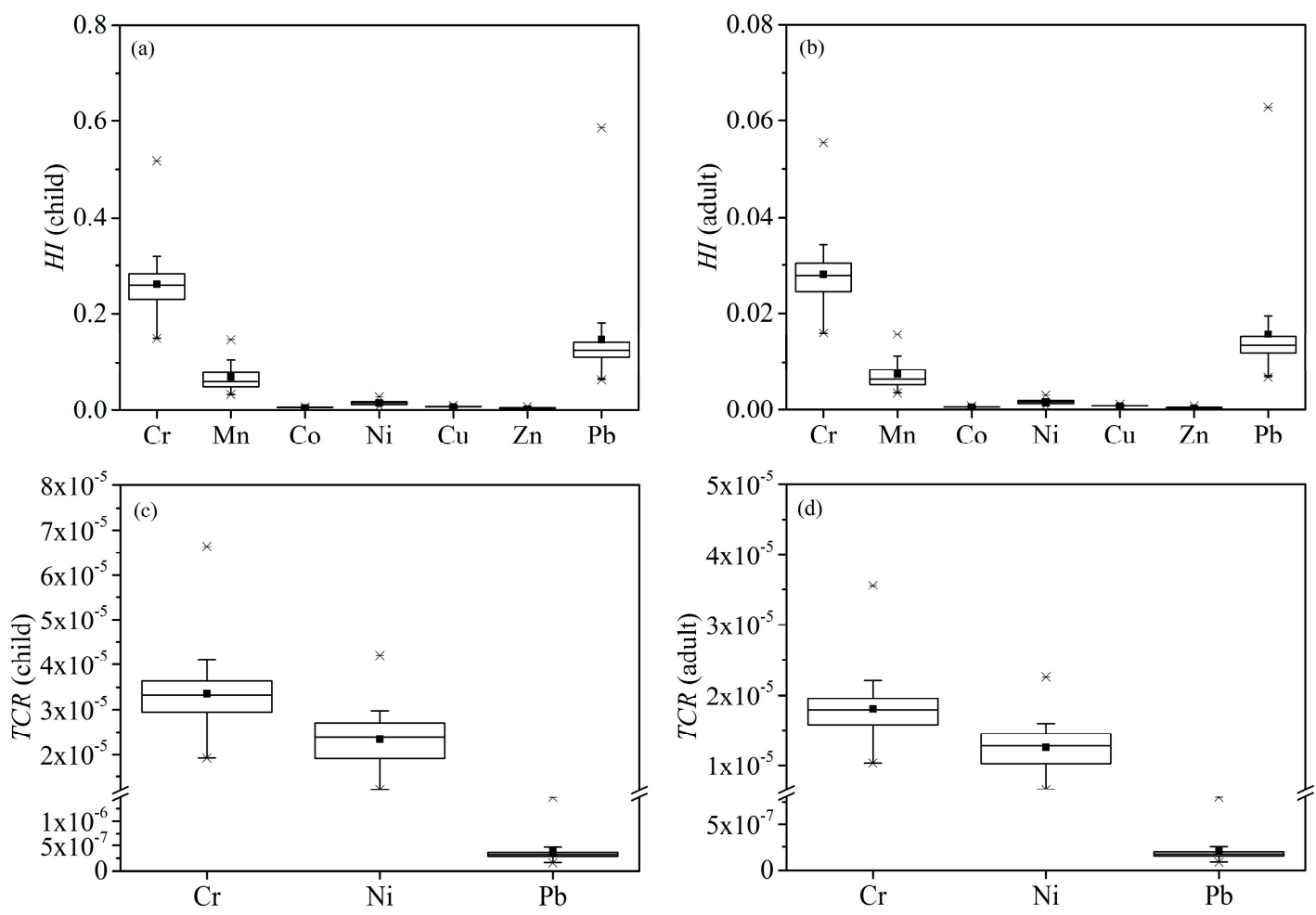

Figure 4. HI and TCR for child and adult of heavy metals. (a) HI for child; (b) HI for adult; (c) TCR for child; (d) TCR for adult.

The TCR values of $\mathrm{Cr}, \mathrm{Ni}$, and $\mathrm{Pb}$ on children were $1.92 \times 10^{-5}-6.65 \times 10^{-5}\left(3.36 \times 10^{-5}\right.$, mean), $1.21 \times 10^{-5}-4.20 \times 10^{-5}\left(2.34 \times 10^{-5}\right)$ and $1.61 \times 10^{-7}-1.49 \times 10^{-6}\left(3.75 \times 10^{-7}\right)$, respectively. For adults, the TCR values of $\mathrm{Cr}, \mathrm{Ni}$, and $\mathrm{Pb}$ were $1.80 \times 10^{-5}, 1.25 \times 10^{-5}$, and $2.01 \times 10^{-7}$ in sequence. As the same with $H I$ values, the TCR values of adults were smaller than the children's values. The maximum acceptable risk level of $1 \times 10^{-4}$ is set by the US EPA, while a TCR less than $1 \times 10^{-6}$ doesnot have dramatic effects on human health. The average TCR values for children and adults suggested that these carcinogenic risk levels caused by $\mathrm{Cr}$ and Ni were acceptable, and $\mathrm{Pb}$ might pose no carcinogenic risk. These findings demonstrated that both children and adults were more easily exposed to $\mathrm{Cr}$ and $\mathrm{Ni}$ than $\mathrm{Pb}$, which may cause an acceptable carcinogenic risk. 


\subsection{Identification of Pollution Sources}

Multivariate statistical analysis, including Pearson's analysis, principal component analysis, (PCA) and cluster analysis (CA), could be used to identify similar origins or geochemical characteristics between the heavy metals when they have inter-relationship [34,35]. The closeness of the relationship between heavy metals $\mathrm{Cr}, \mathrm{Mn}, \mathrm{Co}, \mathrm{Ni}, \mathrm{Cu}, \mathrm{Zn}$, and $\mathrm{Pb}$ could be revealed by Pearson's correlation analysis (Table 4). The Pearson's correlation coefficients of elemental pairs $\mathrm{Cr}$-Co (0.569), $\mathrm{Cr}-\mathrm{Ni}(0.906)$, $\mathrm{Cr}-\mathrm{Cu}$ (0.627), $\mathrm{Co}-\mathrm{Ni}(0.707), \mathrm{Co}-\mathrm{Cu}(0.769)$, and Ni-Cu (0.725) implied that a significant correlation at $p<0.01$ was found among $\mathrm{Cr}, \mathrm{Co}, \mathrm{Ni}$, and $\mathrm{Cu}$. Mn exhibited a significant correlation with $\mathrm{Co}$, and an in apparent correlation with other metals $(\mathrm{Ni}, \mathrm{Cu}, \mathrm{Zn}$, and $\mathrm{Pb}$ ). A significant positive correlation at $p<0.01$ was also observed between $\mathrm{Zn}$ and $\mathrm{Pb}$. Principal component analysis showed that two principal components with an eigenvalue $>1$ occupied appropriately $77.348 \%$ of the total variance (Figure 5a). The first principal component was dominated by $\mathrm{Cr}, \mathrm{Co}, \mathrm{Ni}$, and $\mathrm{Cu}$, explaining $56.142 \%$ of the total variance. The second component was loaded by $\mathrm{Mn}, \mathrm{Zn}$, and $\mathrm{Pb}$, accounting for $21.206 \%$ of the total variance. The factor score plot showed that Station LS04 had a high score in PC2, indicating considerable contamination of $\mathrm{Pb}$, and moderate contamination of $\mathrm{Mn}$ and $\mathrm{Zn}$ (Figure 5b). Station LS09, moderately polluted by $\mathrm{Cr}, \mathrm{Ni}$, and $\mathrm{Pb}$, had a high score in PC1. The between-group linkage was applied to cluster analysis, and Pearson's correlation for similarity in heavy metals was calculated. A dendrogram of cluster analysis helped to group the heavy metals with characteristics and to allow the two groups to be distinguished from one another (Figure 6). Cluster1 contained $\mathrm{Cr}, \mathrm{Ni}, \mathrm{Co}$, and $\mathrm{Cu}$; Cluster2 consisted of the remaining three metals: $\mathrm{Mn}, \mathrm{Zn}$, and $\mathrm{Pb}$.

Table 4. Person's correlation matrix of the heavy metals in the sediments from the Lishui River.

\begin{tabular}{cccccccc}
\hline Heavy Metal & $\mathbf{C r}$ & $\mathbf{M n}$ & $\mathbf{C o}$ & $\mathbf{N i}$ & $\mathbf{C u}$ & $\mathbf{Z n}$ & $\mathbf{P b}$ \\
\hline $\mathrm{Cr}$ & 1 & & & & & & \\
$\mathrm{Mn}$ & 0.233 & 1 & & & & & \\
$\mathrm{Co}$ & $0.569^{* *}$ & $0.674^{* *}$ & 1 & & & & \\
$\mathrm{Ni}$ & $0.906^{* *}$ & 0.259 & $0.707^{* *}$ & 1 & & & \\
$\mathrm{Cu}$ & $0.627^{* *}$ & 0.283 & $0.769^{* *}$ & $0.725^{* *}$ & 1 & & \\
$\mathrm{Zn}$ & 0.193 & 0.417 & 0.414 & 0.258 & $0.442^{*}$ & 1 & \\
$\mathrm{~Pb}$ & 0.243 & 0.34 & 0.423 & 0.233 & $0.476^{*}$ & $0.841^{* *}$ & 1 \\
\hline
\end{tabular}

${ }^{*}$ Correlation is significant at $p<0.05$ (two-tailed); ${ }^{* *}$ Correlation is significant at $p<0.01$ (two-tailed).

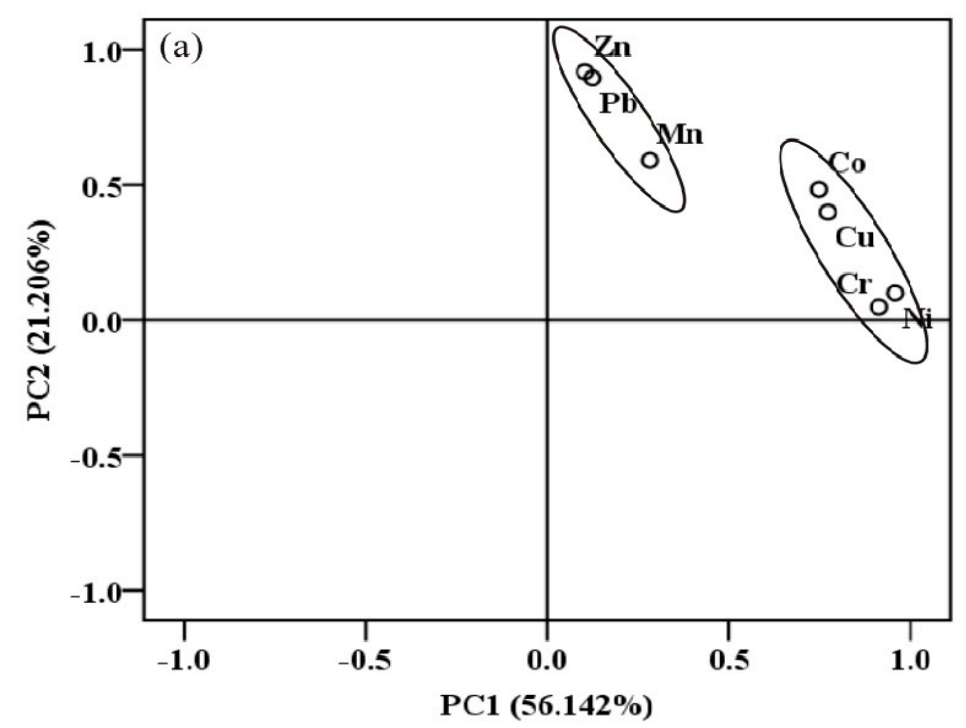

Figure 5. Cont. 


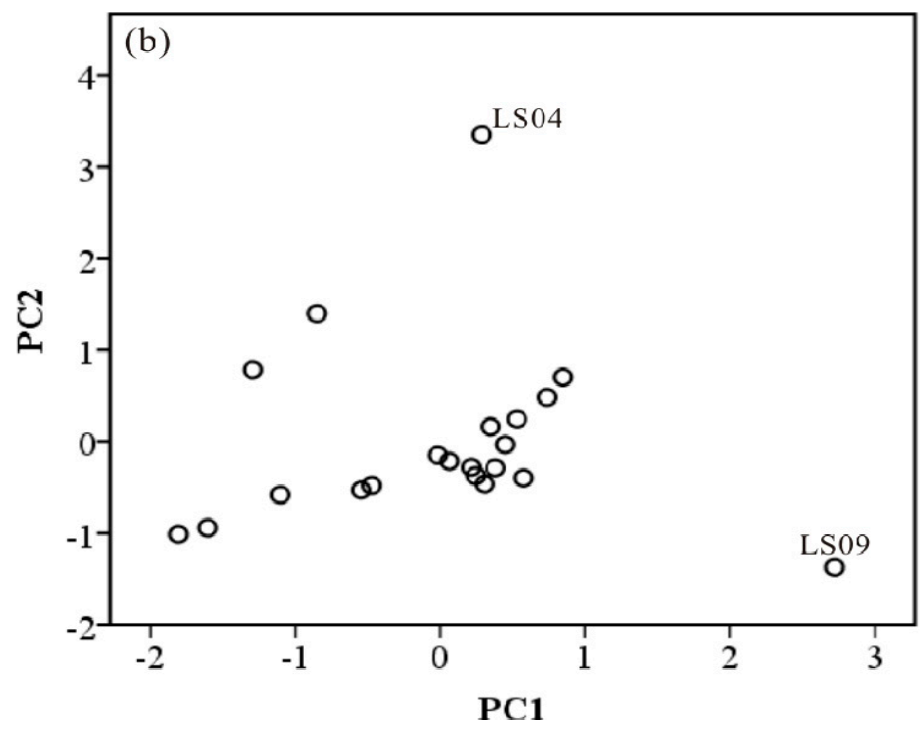

Figure 5. The principal component analysis results heavy metals. (a) Factor loadings; (b) factor scores.

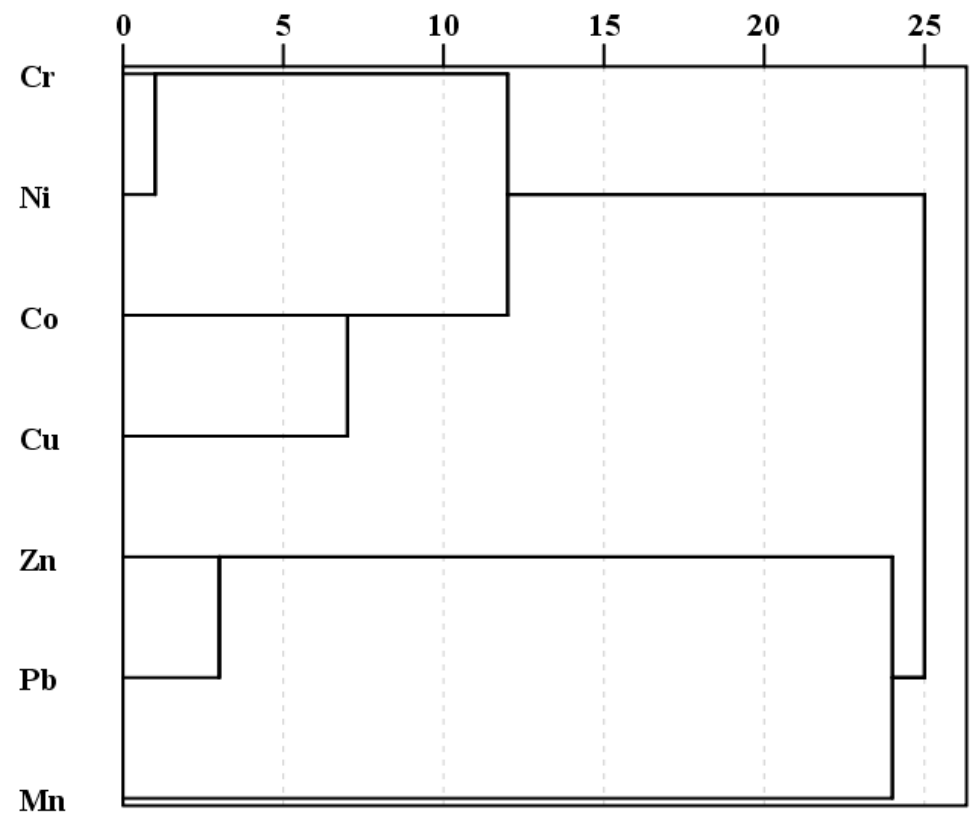

Figure 6. Dendrogram of cluster analysis for heavy metals in the sediment from the Lishui River.

The results of multivariate statistical analysis reached a consensus, indicating that the studied heavy metals were divided into two clusters: (1) $\mathrm{Cr}, \mathrm{Ni}, \mathrm{Co}$, and $\mathrm{Cu}$; (2) $\mathrm{Mn}, \mathrm{Zn}, \mathrm{and} \mathrm{Pb}$. The concentrations of the first species $(\mathrm{Cr}, \mathrm{Ni}, \mathrm{Co}$, and $\mathrm{Cu}$ ) were close to the corresponding background values, which implies that these heavy metals were mainly derived from natural sources. The concentrations of the second species of heavy metals were greater than the corresponding values, which revealed human activities was a major influence. The $\mathrm{Zn}$ concentration of the six stations (LS01, LS02, LS04, LS05, LS18, and LS20) exceeded the background concentration. Zn infiltrated the aquatic system due to petrochemical and industrial effluents, vehicular traffic, fertilizer, and livestock manure [7,41]. Stations LS01, LS02, LS04, and LS05 were located in the Jinshi County. The livestock and poultry industry produced a considerable quantity of manure in Jinshi County, which was a major source of agricultural pollution [42]. All stations polluted by Zn were located in the Liyang plain. Being the origin of world rice farming, Liyang plain's agriculture was advanced, and the environment was polluted by fertilizer and other farm runoff [43]. The moderate pollution of Mn was investigated in the sediments of the Lishui River. The sources of Mn were attributed to agricultural and industrial 
activities, including coal combustion and coal mining [7]. Pollutants produced by agricultural activities in the Liyang plain, such as the employment of pesticides, were discharged into the Lishui River [44]. Many different mine dimensions were distributed in the Lishui River basin, containing nonferrous and ferrous metals $[45,46]$. According to statistics, there were 206 mine enterprises being mined, including open pit mining enterprises and underground mining enterprises [45]. The mining of these minerals brought elements such as $\mathrm{Mn}, \mathrm{Pb}$, and $\mathrm{Hg}$ into the sediment [46]. Pb primarily came from metal plating, vehicle exhaust, fertilizer, and wastewater discharge [41,47]. Industrial estates of Jinshi County, Lixian County, and Shimen County all lay near the Lishui River. Jinshi has been a famous industry center in Hunan Province since the 1970s, and this district's industrial concentration achieved a provincial level. The economy is dominated by this industry. Enterprises, such as the generation of electricity and the manufacturing industry, discharged wastewater during production. The Liyang plain's agricultural activities releases fertilizers into the Lishui River. The area from Shimen to Xiaodukou in the Lishui River was the best navigable reach, and ships under 100t can navigate there throughout the year, and this has caused the pollution of $\mathrm{Pb}$.

\section{Conclusions}

Heavy metals $(\mathrm{Cr}, \mathrm{Mn}, \mathrm{Co}, \mathrm{Ni}, \mathrm{Cu}, \mathrm{Zn}$, and $\mathrm{Pb})$ were measured in the surface sediments from the Lishui River. The mean concentrations of heavy metals were $61.20 \mathrm{mg} / \mathrm{kg}(\mathrm{Cr}), 757.15 \mathrm{mg} / \mathrm{kg}$ (Mn), $9.39 \mathrm{mg} / \mathrm{kg}(\mathrm{Co}), 25.31 \mathrm{mg} / \mathrm{kg}(\mathrm{Ni}), 22.84 \mathrm{mg} / \mathrm{kg}(\mathrm{Cu}), 91.66 \mathrm{mg} / \mathrm{kg}(\mathrm{Zn})$, and $40.19 \mathrm{mg} / \mathrm{kg}$ $(\mathrm{Pb})$, respectively. The spatial distribution of heavy metals was site-specific, exhibiting a remarkably high level in the sampling stations with intense agricultural activities (Lixian) and industrial activities (Jinshi). To investigate the contamination degree, ecological risk, and human health risk of heavy metals in the sediment, contamination factor $(C F)$, pollution load index $(P L I)$, nemerow multi-factor index $(P I)$, potential ecological risk index $(R I)$, and human health risk were employed to assess the pollution degree, potential ecological risk, and human health risk of the river sediments. The results showed that the degree of heavy metals decreased in the order of $\mathrm{Mn}>\mathrm{Pb}>\mathrm{Zn}>\mathrm{Cr}>\mathrm{Cu}>\mathrm{Ni}>\mathrm{Co}$. Heavy metals resulted in non-pollution to moderate pollution, with low ecological risk and an acceptable carcinogenic risk caused by $\mathrm{Cr}$ and Ni for children and adults. Person's correlation analysis, principal component analysis (PCA), and cluster analysis (CA) were applied to identify the sources of heavy metal pollution. The results indicated the sediment from the Lishui River were mainly influenced by two sources: $\mathrm{Cr}, \mathrm{Mn}, \mathrm{Ni}$, and $\mathrm{Cu}$ were mainly derived from natural sources, while $\mathrm{Mn}, \mathrm{Zn}$, and $\mathrm{Pb}$ were originated from agricultural and industrial activities, mining, and vehicular traffic.

Author Contributions: Investigation, L.M. and Z.T.; Data Curation, J.D.; Methodology, F.S.; Software, F.S.; Validation, M.D.; Writing-Original Draft Preparation, J.D. and F.S.; Writing-Review \& Editing, L.M., R.S. and F.S.

Acknowledgments: The authors gratefully acknowledge the financial support of the National Nature Science Foundation of China (Nos. 41771218 and 41703100), and the Jiangsu Qinglan Project, and the Priority Academic Program Development of Jiangsu Higher Education Institutions (PAPD).

Conflicts of Interest: There are no conflict of interest to declare.

\section{References}

1. Salomons, W.; Stigliani, W.M. Biogeodynamics of Pollutants in Soils and Sediments; Springer: Berlin, Germany, 1995.

2. Adams, W.J.; Kimerle, R.A.; Barnett, J.W., Jr. Sediment quality and aquatic life assessment. Environ. Sci. Technol. 1992, 26, 1864-1875. [CrossRef]

3. Ikem, A.; Egiebor, N.O.; Nyavor, K. Trace Elements in Water, Fish and Sediment from Tuskegee Lake, Southeastern USA. Water Air Soil Pollut. 2003, 149, 51-75. [CrossRef]

4. Zheng, B.; Lu, S.; Wu, J.; Guo, X.; Wu, F.; Li, X.; He, Q.; Fu, Z.; Xu, L. Heavy metal distribution in Tiaoxi River's sediment. Environ. Sci. Pollut. Res. 2018, 25, 2603-2613. [CrossRef] [PubMed]

5. Zhuang, Q.; Li, G.; Liu, Z. Distribution, source and pollution level of heavy metals in river sediments from South China. Catena 2018, 170, 386-396. [CrossRef] 
6. Keshavarzi, B.; Mokhtarzadeh, Z.; Moore, F.; RastegariMehr, M.; Lahijanzadeh, A.; Rostami, S.; Kaabi, H. Heavy metals and polycyclic aromatic hydrocarbons in surface sediments of Karoon River, Khuzestan Province, Iran. Environ. Sci. Pollut. Res. 2015, 22, 19077-19092. [CrossRef] [PubMed]

7. Liu, J.; Liu, Y.J.; Liu, Y.; Liu, Z.; Zhang, A.N. Quantitative contributions of the major sources of heavy metals in soils to ecosystem and human health risks: A case study of Yulin, China. Ecotoxicol. Environ. Saf. 2018, 164, 261-269. [CrossRef] [PubMed]

8. Kusin, F.M.; Azani, N.N.M.; Hasan, S.N.M.S.; Sulong, N.A. Distribution of heavy metals and metalloid in surface sediments of heavily-mined area for bauxite ore in Pengerang, Malaysia and associated risk assessment. Catena 2018, 165, 454-464. [CrossRef]

9. Ramachandra, T.V.; Sudarshan, P.B.; Mahesh, M.K.; Vinay, S. Spatial patterns of heavy metal accumulation in sediments and macrophytes of Bellandur wetland, Bangalore. J. Environ. Manag. 2018, 206, 1204-1210. [CrossRef] [PubMed]

10. Wang, X.; Gu, Y.; Wang, Z.; Ke, C.; Mo, M. Biological risk assessment of heavy metals in sediments and health risk assessment in bivalve mollusks from Kaozhouyang Bay, South China. Mar. Pollut. Bull. 2018, 133, 312-319. [CrossRef] [PubMed]

11. Hu, D. Studies on the Rainfall Characteristics and the Agricultural Water Resource Utilization in the Lishui River Basin; Hunan Agricultural University: Changsha, Hunan, China, 2009; Volume 69. (In Chinese)

12. Qi, H.; Chen, W.; Lan, W. A study on the assessment of resources and economy and the model of development in the mid-lower valley of Lishui River. J. Changde Teach. Univ. (Soc. Sci. Ed.) 2001, 26, 57-59. (In Chinese)

13. Guo, Y.; Mo, D.; Mao, L.; Jin, Y.; Guo, W.; Mudie, P.J. Settlement distribution and its relationship with environmental changes from the Paleolithic to Shang-Zhou period in Liyang Plain, China. Quat. Int. 2014, 321, 29-36. [CrossRef]

14. Zeng, D.; Peng, B.; Zhang, K.; Fang, X.; Tan, C.; Kuang, X.; Wu, B.; Tu, X. Characteristics and assessment of heavy metal contamination in bed sediments from inlet areas of the Lishui River to Dongting Lake. Acta Sci. Circumst. 2017, 37, 3480-3488. (In Chinese)

15. Zhang, G.; Huang, B. Health risk assessment of heavy metals in Dongting Lake water system in Hunan Province, China. Water Resour. Prot. 2014, 6, 41-71. (In Chinese)

16. Li, F.; Huang, J.; Zeng, G.; Yuan, X.; Li, X.; Liang, J.; Wang, X.; Tang, X.; Bai, B. Spatial risk assessment and sources identification of heavy metals in surface sediments from the Dongting Lake, Middle China. J. Geochem. Explor. 2013, 132, 75-83. [CrossRef]

17. Mo, J.; Xia, W.; Luo, Y. Analysis of soil erosion and soil conservation measures in Lishui River basin. Anhui Agric. Sci. Bull. 2009, 15, 75-76. (In Chinese)

18. Du, Y.; Cai, S.; Zhang, X.; Zhao, Y. Interpretation of the environmental change of Dongting Lake, middle reach of Yangtze River, China, by $210 \mathrm{~Pb}$ measurement and satellite image analysis. Geomorphology 2001, 41, 171-181. [CrossRef]

19. Li, J. Analysis of hydrological characteristics in Lishui River basin. J. Nat. Sci. Hun. Norm. Univ. 1991, 14, 267-272. (In Chinese)

20. Xiao, L.; Yan, D. Thoughts and Suggestions on integrated resource management and development and utilization of Xiangjiang, Zishui, Yuanjiang and Lishui River. Water Resour. Plan. Des. 2008, 3-6. (In Chinese)

21. Mao, L.; Mo, D.; Guo, Y.; Fu, Q.; Yang, J.; Jia, Y. Multivariate analysis of heavy metals in surface sediments from lower reaches of the Xiangjiang River, southern China. Environ. Earth Sci. 2013, 69, 765-771. [CrossRef]

22. Song, Y.; Ji, J.; Yang, Z.; Yuan, X.; Mao, C.; Frost, R.L.; Ayoko, G.A. Geochemical behavior assessment and apportionment of heavy metal contaminants in the bottom sediments of lower reach of Changjiang River. Catena 2011, 85, 73-81. [CrossRef]

23. Dai, L.; Wang, L.; Li, L.; Liang, T.; Zhang, Y.; Ma, C.; Xing, B. Multivariate geostatistical analysis and source identification of heavy metals in the sediment of Poyang Lake in China. Sci. Total Environ. 2018, 621, 1433-1444. [CrossRef] [PubMed]

24. Hakanson, L. An ecological risk index for aquatic pollution control: A sediment ecological approach. Water Res. 1980, 14, 975-1001. [CrossRef]

25. CNEMC (China National Environmental Monitoring Center). The Background Concentrations of Soil Elements in China; China Environmental Science Press: Beijing, China, 1990. (In Chinese) 
26. Tomlinson, D.L.; Wilson, J.G.; Harris, C.R.; Jeffrey, D.W. Problems in the assessment of heavy-metal levels in estuaries and the formation of a pollution index. Helgoländer Meeresuntersuchungen 1980, 33, 566-575. [CrossRef]

27. Nemerow, N.L. Stream, Lake, Estuary, and Ocean Pollution; Van Nostrand Reinhold: New York, NY, USA, 1991.

28. Yan, N.; Liu, W.; Xie, H.; Gao, L.; Han, Y.; Wang, M.; Li, H. Distribution and assessment of heavy metals in the surface sediment of Yellow River, China. J. Environ. Sci. China 2016, 39, 45-51. [CrossRef]

29. Kolluru, R.V.; Bartell, S.M.; Pitblado, R.M.; Stricoff, R.S. Risk Assessment and Management Handbook; McGrow-Hill: New York, NY, USA, 1996.

30. NRC (National Research Council); NAS (National Academy of Sciences). Risk Assessment in the Federal Government: Managing the Process; National Academy Press: Washington, DC, USA, 1983.

31. US EPA. Risk Assessment Guidance for Superfund Volume 1 Human Health Evaluation Manual (Part A); Office of Emergency and Remedial Response: Washington, DC, USA, 1989.

32. US EPA. Supplemental Guidance for Developing Soil Screening Levels for Superfund Sites; Office of Emergency and Remedial Response: Washington, DC, USA, 2002.

33. US EPA. Integrated Risk Information System of the US Environmental Protection Agency; Office of Emergency and Remedial Response: Washington, DC, USA, 2012.

34. Li, X.; Liu, L.; Wang, Y.; Luo, G.; Chen, X.; Yang, X.; Hall, M.H.P.; Guo, R.; Wang, H.; Cui, J.; et al. Heavy metal contamination of urban soil in an old industrial city (Shenyang) in Northeast China. Geoderma 2013, 192, 50-58. [CrossRef]

35. Lu, X.; Wang, L.; Li, L.Y.; Lei, K.; Huang, L.; Kang, D. Multivariate statistical analysis of heavy metals in street dust of Baoji, NW China. J. Hazard. Mater. 2010, 173, 744-749. [CrossRef]

36. Zhang, Z.; Lu, Y.; Li, H.; Tu, Y.; Liu, B.; Yang, Z. Assessment of heavy metal contamination, distribution and source identification in the sediments from the Zijiang River, China. Sci. Total Environ. 2018, 645, 235-243. [CrossRef]

37. Chai, L.; Li, H.; Yang, Z.; Min, X.; Liao, Q.; Liu, Y.; Men, S.; Yan, Y.; Xu, J. Heavy metals and metalloids in the surface sediments of the Xiangjiang River, Hunan, China: Distribution, contamination, and ecological risk assessment. Environ. Sci. Pollut. Res. 2017, 24, 874-885. [CrossRef]

38. Malvandi, H. Preliminary evaluation of heavy metal contamination in the Zarrin-Gol River sediments, Iran. Mar. Pollut. Bull. 2017, 117, 547-553. [CrossRef]

39. Rodríguez-Espinosa, P.F.; Shruti, V.C.; Jonathan, M.P.; Martinez-Tavera, E. Metal concentrations and their potential ecological risks in fluvial sediments of Atoyac River basin, Central Mexico: Volcanic and anthropogenic influences. Ecotoxicol. Environ. Saf. 2018, 148, 1020-1033. [CrossRef]

40. Green-Ruiz, C.; Paez-Osuna, F. Heavy metal anomalies in lagoon sediments related to intensive agriculture in Altata-Ensenada del Pabellon coastal system (SE Gulf of California). Environ. Int. 2001, 26, 265-273. [CrossRef]

41. Abbasi, S.A.; Abbasi, N.; Soni, R. Heavy Metals in the Environment; Oscar Publication: St. Albans, UK, 2005.

42. Zhu, Z.; Xu, G. Investigation on pollution control of breeding industry in Jinshi County. Prim Agric. Technol. Ext. 2016, 4, 89-90. (In Chinese)

43. Liang, J. Study on Prehistoric Agriculture in Liyang Plain Located Dongting Lake Area; South China Agricultural University: Guangzhou, Guangdong, China, 2006. (In Chinese)

44. Pignata, M.L.; Gudiño, G.L.; Wannaz, E.D.; Plá, R.R.; González, C.M.; Carreras, H.A.; Orellana, L. Atmospheric quality and distribution of heavy metals in Argentina employing Tillandsia capillaris as a biomonitor. Environ. Pollut. 2002, 120, 59-68. [CrossRef]

45. Li, A. Mining-induced earthquake in Lishui River basin. South China J. Seismol. 2010, 30, 105-112. (In Chinese)

46. Tong, T. Element concentrations in river delta sediments and mineral resources potential in the drainage basin: A case study in the Xiangjiang, Zishui, Yuanjiang, and Lishui rivers basins. Quant. Sci. 2005, 25, 298-305. (In Chinese)

47. Men, C.; Liu, R.; Xu, F.; Wang, Q.; Guo, L.; Shen, Z. Pollution characteristics, risk assessment, and source apportionment of heavy metals in road dust in Beijing, China. Sci. Total Environ. 2018, 612, 138-147. [CrossRef]

(C) 2019 by the authors. Licensee MDPI, Basel, Switzerland. This article is an open access article distributed under the terms and conditions of the Creative Commons Attribution (CC BY) license (http:/ / creativecommons.org/licenses/by/4.0/). 